\title{
Cervical Ripening: Comparative Study between Intracervical Balooning by Foley's Catheter and Intravaginal Misoprostol Tablet
}

\author{
J FERDOUS $^{\mathrm{a}}$, NN KHANAM ${ }^{\mathrm{b}}$, MR BEGUM ${ }^{\mathrm{c}}$, S AKHTER $^{\mathrm{d}}$
}

\begin{abstract}
Summary:
This study was designed to compare the effectiveness of misoprostol and Foley's catheter on cervical ripening.

A randomized clinical trial was carried out at Dhaka Medical College Hospital during the period from March 2002 to November 2002. Ninety patients, who were chosen for induction, were selected for this study, 45 patients were randomly selected for Foley's catheter group and 45 patients for misoprostol group by using lottery. The baseline characteristics like age, parity, socioeconomic condition, gestational age; Bishop's score and indication of induction of labor were almost same in both groups.

Mean duration of onset of labour was 13.60 \pm 5.0 and $15.26 \pm 3.58$ hours, induction-full dilatation was $18.83 \pm 2.94$
\end{abstract}

\section{Introduction:}

Induction of labour is a standard obstetric approach by which pregnancy is terminated artificially any time after the age of viability. Induction of labour should be considered when further prolongation of pregnancy might expose the mother or fetus or both to certain risk and when vaginal delivery is not contraindicated. Common indications for labour are prolonged pregnancy, diabetes mellitus, Rhisoimmunization, pre-eclampsia, chronic hypertension, placental insufficiency, intrauterine

\footnotetext{
a. Dr. Jannatul Ferdous, FCPS (Obs \& Gynae)

b. Dr. Nurun Nahar Khanam, FCPS, MS (Obs \& Gynae)

c. Dr. Most. Rashida Begum, FCPS (Obs \& Gynae)

d. Prof. Sayeba Akhter, FCPS (Obs \& Gynae)
}

Obstetrics and Gynaecology Department of Dhaka Medical College and Hospital, Dhaka, Bangladesh

Address of Correspondence: Dr. Jannatul Ferdous, FCPS (Obs \& Gynae), Assistant Professor, Department of Obstetrics and Gynaecology, Bangabandhu Sheikh Mujib Medical University, Phone: 01711607919.

Received: 27 December, 2006

Accepted: 21 September, 2008 and $20.03 \pm 2.46$ hours and induction-delivery interval was $20.04 \pm 2.82$ and $21.18 \pm 2.32$ hours in the misoprostol and Foley's catheter groups respectively. The differences were not significant. Mode of delivery and fetal outcome were also same in both group. Complications like vomiting and hyperstimulation appeared in few cases in misoprostol group but not significant.

From this study, it was found that the safety and efficacy of Foley's catheter is comparable to misoprostol. In addition, Foley's catheter is free from some side effects of misoprostol, like vomiting and hyperstimulation. Therefore, Foley's catheter can be used for cervical ripening.

Key words: Induction of labor, Foley's catheter, misoprostol.

(J Bangladesh Coll Phys Surg 2009; 27: 5-12)

growth retardation (IUGR), intrauterine death (IUD) and congenital malformation of fetus. ${ }^{1}$

The principal concern is how to provide the most effective, easy to use, safest and less expensive way to terminate the pregnancy. The success of induction depends on the consistency, compliance and configuration of the cervix. In approximately 10 percent of all pregnancies, women have unfavourable cervix; and when labour is induced in an unripe cervix, it is associated with higher than normal incidence of failure of induction, prolonged labour, instrumental delivery and Caesarean section. ${ }^{2}$

The unripe cervix is known to impede labour induction. So, careful evaluation of the cervix is predictive of the potential success of induction and is highly recommended before induction. Cervical ripening can be accomplished mechanically or medically using hormones and thus increase the success rate of induction of labour. These include: (a) oxytocin, (b) intravaginal, intracervical of extraamniotic application of prostaglandins, (c) intravaginal administration of oestradiol, (d) intracervical placement of osmotic dilators (e) 
stripping the membrane, and (f) amniotomy. ${ }^{3}$

Numerous studies have shown locally applied prostaglandins ( $\mathrm{PG}$ ), principally $\mathrm{PGE}_{2}$ and $\mathrm{PGE}_{1}$, to increase cervical compliance and dilatation. Prostaglandin E-induced cervical ripening is associated with enzymatic collagen degradation and increased water content in the cervical extracellular matrix. Independent of their local effects on the cervix, PGs also stimulates the myometrium, resulting in uterine contractions. Misoprostol, a synthetic prostaglandin $\mathrm{E}_{1}$ analogue, which was initially used in peptic ulcer treatment, is a promising agent in cervical ripening. Possible advantages of misoprostol may be the cost effectiveness, ease of administration, well tolerability and most notably, its dual action in cervical ripening and labour induction. ${ }^{4}$

Mechanical methods of cervical ripening act primarily by dilating and stretching the lower uterine segment and cervix. Several studies suggest that cervical ripening with an extraamniotic catheter balloon has advantages of simplicity, low cost, reversibility and lack of systemic or serious sideeffect. Moreover, the ripening efficiency of the catheter balloon is better or similar to that with local misoprostol. ${ }^{5}$

This study was designed to find out the effectiveness and safety of Foley's catheter and misoprostol in cervical ripening and induction of labor.

\section{Material and Methods:}

This is a randomized clinical trial conducted in the Department of Obstetrics and Gynaecology, Dhaka Medical College Hospital (DMCH) from March to November, 2002. The methods and purpose of the study were explained to the patients and only those who agreed were finally selected. Written consent was taken from each respondent. The inclusion criteria were intact membrane, singleton pregnancies, cephalic presentation, low Bishop score $(\leq 5)$ and pregnancies after the age of viability. Patients with vaginal infection, placenta preavia, low-lying placenta, unexplained vaginal bleeding, presentation other than head and previous caesarean section were excluded from the study. A total 90 patients were randomly selected for this study. All patients came during the study period were included. All patients were divided into two groups by simple lottery method. Group-I was the misoprostol group $(n=45)$, where misoprostol vaginal tablet was used for cervical ripening. Group-II $(n=45)$ was Foley's catheter group, where cervical ripening was done by using intracervical extraamniotic Foley's catheter.

A formal scoring of the cervix was done by Bishop's scoring system before induction.

In the first group misoprostol was introduced. The misoprostol dosing regimen was $50 \mu \mathrm{g}$ (one-fourth of a $200 \mu \mathrm{g}$ tablet prepared by the pharmacist in India) inserted intravaginally (in the posterior vaginal fornix), every 6 hour for a maximum of four doses, that is $200 \mu \mathrm{g}$. Following insertion, close monitoring of fetal heart rate and observation was done to detect hyperstimulation,. Cervical score was reassessed after 4 hours. Before administration of subsequent doses of misoprostol, the patient's contraction frequency was evaluated manually. If the patient was having 1-3 contractions/10 minutes, she was observed for evidence of progressive cervical dilatation (at least 1 $\mathrm{cm}$ per hour). If labour was progressing, then no more dose was given and labor was observed. But if cervix was not riped after 6 hours, the dose was repeated 6 hourly to maximum of 4 doses. If contraction was not adequate labor was augmented by ARM or oxytocin or by both.

Partograph was maintained once the patient went into active labour. If cervical dilatation did not progress for 4 hours and more during the active phase of labour, intravenous oxytocin was used for augmentation.

In the second group an 18-sized Foley's catheter was introduced through the cervix using a sterile technique with the aid of a speculum and spongeholding forceps. No cleansing of the cervix was performed. Every effort was made to avoid contact of the vagina or ectocervix with the Foley's catheter. The Foley's catheter was advanced into the endocervical canal. Once it has passed the internal os, $30 \mathrm{ml}$-distilled water is instilled into the balloon.

The catheter was placed on traction by taping the end of the catheter to inside of the patient's thigh on minimal traction. Prophylactic antibiotic, ampicillin was given to all patients. When the patient went into active labor (defined as regular contraction, 3/10 minutes), she was sent to the observation ward and 
followed as the first group. If, despite expulsion of the catheter, the patient did not go into the established labour within 1 hour, ARM was performed and oxytocin drip was administrated. The procedure was considered to have failed if catheter was in situ for 24 hours without onset of labour pain or cervical dilation.

\section{Results:}

There was no significant difference in mean age, height, weight, socioeconomic status, parity, gravidity, gestational age and Bishop's score among misoprostrol and Foley's catheter group (Table-I).

Table-I

\begin{tabular}{|c|c|c|c|}
\hline \multicolumn{4}{|c|}{ Characteristics of the study subjects } \\
\hline Parameters & $\begin{array}{l}\text { Misoprostol } \\
\text { group }(n=45)\end{array}$ & $\begin{array}{c}\text { Foley's } \\
\text { catheter } \\
\text { group }(n=45)\end{array}$ & $P$ value ${ }^{a}$ \\
\hline $\begin{array}{l}\text { Age (years) } \\
(\text { Mean } \pm \text { SD) }\end{array}$ & $25.33 \pm 5.09$ & $25.27 \pm 4.93$ & $0.950^{\mathrm{NS}}$ \\
\hline $\begin{array}{l}\text { Height }(\mathrm{cm}) \\
(\text { Mean } \pm \text { SD) }\end{array}$ & $147.50 \pm 5.65$ & $148.40 \pm 6.25$ & $0.932^{\mathrm{NS}}$ \\
\hline $\begin{array}{l}\text { Weight (kg) } \\
(\text { Mean } \pm \text { SD) }\end{array}$ & $52.20 \pm 3.1$ & $53.3 .0 \pm 4.2$ & $0.841^{\mathrm{NS}}$ \\
\hline $\begin{array}{l}\text { Parity } \\
\text { (Median) }\end{array}$ & 1.0 & 1.0 & \\
\hline $\begin{array}{l}\text { Gravidity } \\
\text { (Median) }\end{array}$ & 2.0 & 2.0 & \\
\hline $\begin{array}{l}\text { Gestational age } \\
(\text { weeks })(\text { Mean } \pm \text { SD) }\end{array}$ & $36.37 \pm 5.04$ & $36.24 \pm 4.96$ & $0.689^{\mathrm{NS}}$ \\
\hline $\begin{array}{l}\text { Bishop's score } \\
(\text { Mean } \pm \mathrm{SD})\end{array}$ & $3.20 \pm 1.20$ & $3.62 \pm 1.27$ & $0.108^{\mathrm{NS}}$ \\
\hline
\end{tabular}

aUnpaired Student's ' $\mathrm{t}$ ' test

${ }^{N S}$ Not significant

Indications of labour induction were postdated pregnancy in $19(42.2 \%)$ and $17(37.8 \%)$ cases, intrauterine death in $12(26.7 \%)$ and $13(28.9 \%)$ cases, eclampsia in $5(11.1 \%)$ and $5(11.1 \%)$ cases, preeclampsia in $6(13.3 \%)$ and $5(11.1 \%)$, and congenital malformation in $3(6.7 \%)$ and $5(11.1 \%)$ cases in misoprostol and Foley's catheter groups, respectively (Table-II). Statistical comparisons of the clinical parameters between groups were not significant.
Table-II

\begin{tabular}{lcccccc}
\multicolumn{5}{c}{ Indication for labour induction } \\
Indications & \multicolumn{5}{c}{$\begin{array}{c}\text { Misoprostol } \\
\text { group }(\mathrm{n}=45)\end{array}$} & \multicolumn{4}{c}{$\begin{array}{l}\text { Foley's } \\
\text { catheter } \\
\text { group }(\mathrm{n}=45)\end{array}$} & P value $^{\mathrm{a}}$ \\
& No. & $(\%)$ & No. & $(\%)$ & \\
\hline $\begin{array}{l}\text { Postdated } \\
\text { Pregnancy }\end{array}$ & 19 & $(42.2)$ & 17 & $(37.8)$ & $1.000^{\mathrm{NS}}$ \\
$\begin{array}{l}\text { Intrauterine } \\
\text { death (IUD) }\end{array}$ & 12 & $(26.7)$ & 13 & $(28.9)$ & $1.000^{\mathrm{NS}}$ \\
$\begin{array}{l}\text { Eclampsia } \\
\text { Preeclampsia }\end{array}$ & 5 & $(11.1)$ & 5 & $(11.1)$ & $1.000^{\mathrm{NS}}$ \\
$\begin{array}{l}\text { Congenital } \\
\text { malformation }\end{array}$ & 3 & $(6.7)$ & 5 & $(11.1)$ & $1.000^{\mathrm{NS}}$ \\
\hline $\begin{array}{l}\text { a Z-test } \\
\text { NS Not significant }\end{array}$ & & & & & & \\
\hline
\end{tabular}

After initiation of induction of labour, membrane ruptured spontaneously in 18 cases, $9(20 \%)$ in each study group. But in the remaining 72 cases, either artificial rupture of membrane or oxytocin or both were required. Table-III shows the distribution of type of augmentations required in the two groups of patients. Oxytocin drip was required in $7(15.6 \%)$ and $9(20 \%)$, artificial rupture membrane (ARM) required in $27(60 \%)$ and 17 (37.8\%), and both oxytocin drip and ARM required in $12(26.7 \%)$ and $10(22.2 \%)$ cases in misoprostol and Foley's catheter groups, respectively. Statistical analyses showed no significant differences between the groups.

\section{Table-III}

Comparison of augmentation required in misoprostol and Foley's catheter groups

\begin{tabular}{lcccccc} 
& \multicolumn{5}{c}{$\begin{array}{c}c \\
\text { Foley's } \\
\text { catheter }\end{array}$} \\
Augmentations & \multicolumn{2}{c}{ group $(\mathrm{n}=45)$} & \multicolumn{2}{c}{ group $(\mathrm{n}=45)$} & P value $^{\mathrm{a}}$ \\
& No. & $(\%)$ & \multicolumn{2}{c}{ No. } & $(\%)$ & \\
\hline Oxytocin drip & 7 & $(15.6)$ & 9 & $(20.0)$ & $0.581^{\mathrm{NS}}$ \\
ARM & 27 & $(37.8)$ & 17 & $(37.8)$ & $1.000^{\mathrm{NS}}$ \\
ARM+ & 12 & $(60 \%)$ & 10 & $(22.2)$ & $0.624^{\mathrm{NS}}$ \\
Oxytocin drip & & & & & \\
None & 9 & $(20.0)$ & 9 & $(20.0)$ & $1.000^{\mathrm{NS}}$ \\
\hline
\end{tabular}

${ }^{\mathrm{a}}$ Chi-square test

${ }^{\text {NS Not significant }}$

Changes in cervical score developed after 6 hour and 12 hour in two study groups is shown in table IV. The 
initial Cervical score in Misoprostol group was $3.20 \pm 1.20$ and in Foley's catheter group was $3.62 \pm 1.27$. Cervical score after six hours was $6.10 \pm 1.46$ and $5.87 \pm 1.32$ and after 12 hours was $8.35 \pm 1.34$ and $7.79 \pm 1.68$ respectively in both groups. Statistical analyses showed no significant differences between the groups in terms of cervical score after 6 hours and 12 hours.

\section{Table-IV}

\begin{tabular}{|c|c|c|c|}
\hline Group & $\begin{array}{l}\text { Initial cervical } \\
\text { score }\end{array}$ & $\begin{array}{l}\text { Cervical } \\
\text { score after } \\
6 \text { hours }\end{array}$ & $\begin{array}{l}\text { Cervical } \\
\text { score after } \\
12 \text { hours }\end{array}$ \\
\hline $\begin{array}{l}\text { Misoprostol } \\
\text { group }(n=45)\end{array}$ & $3.20 \pm 1.20$ & $6.10 \pm 1.46$ & $8.35 \pm 1.34$ \\
\hline $\begin{array}{l}\text { Foley's catheter } \\
\text { group }(n=45)\end{array}$ & $3.62 \pm 1.27$ & $5.87 \pm 1.32$ & $7.79 \pm 1.68$ \\
\hline$P$ value & $0.108^{\mathrm{NS}}$ & $0.817^{\mathrm{NS}}$ & $0.781^{\mathrm{NS}}$ \\
\hline
\end{tabular}

Comparison of induction-labour pain interval, induction full-dilatation interval and inductiondelivery interval between the two study groups are shown in table-V. Mean $( \pm \mathrm{SD})$ duration of onset of labour was $13.60 \pm 5.0$ and $15.26 \pm 3.58$ hours, induction-full dilatation interval was $18.83 \pm 2.94$ and $20.03 \pm 2.46$ hours and induction-delivery interval was $20.04 \pm 2.82$ and $21.18 \pm 2.32$ hours in the misoprostol and Foley's catheter groups, respectively. Comparison of mean differences of these parameters between the groups showed no significant difference.

\section{Table-V}

Comparison of intrapartum variables between the two study groups

\section{Foley's}

Misoprostol catheter

$\begin{array}{lccc}\text { Parameters } & \left(\mathrm{Mean} \_\mathrm{SD}\right) & (\mathrm{Mean}+\mathrm{SD}) & \mathrm{P}_{-} \text {value }^{\mathrm{a}} \\ \begin{array}{l}\text { Induction-labour } \\ \text { pain interval }\end{array} & \begin{array}{c}13.60 \pm 5.0 \\ (\mathrm{n}=45)\end{array} & \begin{array}{c}15.26 \pm 3.58 \\ (\mathrm{n}=45)\end{array} & 0.074^{\mathrm{NS}} \\ & & \end{array}$

(hours)

$\begin{array}{lccc}\begin{array}{l}\text { Induction-full } \\ \text { dilatation } \\ \text { interval (hours })\end{array} & \begin{array}{c}18.83 \pm 2.94 \\ (\mathrm{n}=36)\end{array} & \begin{array}{c}20.03 \pm 2.46 \\ (\mathrm{n}=37)\end{array} & 0.064^{\mathrm{NS}} \\ \begin{array}{l}\text { Induction-delivery } \\ \text { interval (hours })\end{array} & \begin{array}{c}20.04 \pm 2.82 \\ (\mathrm{n}=36)\end{array} & \begin{array}{c}21.18 \pm 2.32 \\ (\mathrm{n}=37)\end{array} & 0.064^{\mathrm{NS}} \\ \begin{array}{l}\text { anpaired Student's ' } \mathrm{t} \text { ' test } \\ \text { NS Not significant }\end{array}\end{array}$

Number of doses (one dose equals to one-fourth of a tablet) of misoprostol required for cervical ripening are 3 doses in sixteen (35.6\%) cases, 2 doses in 13 $(28.9 \%)$ cases, 4 doses in $10(22.2 \%)$ cases and 1 dose in $6(13.3 \%)$ cases .

Overall, 73 babies were delivered vaginally without any remarkable complication, but 17 mothers required Caesarean section delivery. Group wise, 36 $(80 \%)$ women in misoprostol group and $37(82.2 \%)$ women in Foley's catheter group were delivered vaginally. The differences were not statistically significant (Table-VI). However, Caesarean deliveries were $9(20 \%)$ and $8(17.8 \%)$ in misoprostol and Foley's catheter groups, respectively, which is also not significant.

\section{Table-VI}

Comparison of mode of delivery between the two groups

\begin{tabular}{|c|c|c|c|c|c|}
\hline \multirow[t]{2}{*}{ Mode of delivery } & \multicolumn{2}{|c|}{$\begin{array}{l}\text { Misoprostol } \\
\text { group }(n=45)\end{array}$} & \multicolumn{2}{|c|}{$\begin{array}{c}\text { Foley's } \\
\text { catheter } \\
\text { group }(n=45)\end{array}$} & \multirow[t]{2}{*}{$\mathrm{P}$ value ${ }^{\mathrm{a}}$} \\
\hline & No. & $(\%)$ & No. & $(\%)$ & \\
\hline Vaginal & 36 & $(80.0)$ & 37 & (82.2) & $0.788^{\mathrm{NS}}$ \\
\hline Caesarean & 9 & $(20.0)$ & 8 & (17.8) & $0.788^{\mathrm{NS}}$ \\
\hline
\end{tabular}

aChi-square test

${ }^{\mathrm{NS}}$ Not significant

Caesarean section was higher in misoprostol group because of uterine hyperstimulation in 3 cases $(33.3 \%)$. Eclampsia with recurrent convulsion was present in $2(22.2 \%)$ cases in both the groups. Fetal distress was present in $4(44.4 \%)$ cases of misoprostol and $6(75 \%)$ cases of Foley's catheter group (TableVII). Regarding indications of Caesarean section, no statistically significant difference was observed between the groups.

\section{Table-VII}

\begin{tabular}{|c|c|c|c|c|c|}
\hline \multicolumn{6}{|c|}{ Indications for Caesarean section } \\
\hline \multirow[t]{2}{*}{ Indications } & \multicolumn{2}{|c|}{$\begin{array}{l}\text { Misoprostol } \\
\text { group }(n=9)\end{array}$} & \multicolumn{2}{|c|}{$\begin{array}{c}\text { Foley's } \\
\text { catheter } \\
\text { group }(n=8)\end{array}$} & \multirow[t]{2}{*}{ P value } \\
\hline & No. & $(\%)$ & No. & $(\%)$ & \\
\hline Fetal distress & 4 & $(44.4)$ & 6 & $(75.0)$ & $0.201^{\mathrm{NS}}$ \\
\hline Hyper stimulation & n 3 & $(33.3)$ & 0 & & $0.072^{\mathrm{NS}}$ \\
\hline $\begin{array}{l}\text { Eclampsia with } \\
\text { recurrent convul }\end{array}$ & $\begin{array}{l}2 \\
\text { Ilsion }\end{array}$ & $(22.2)$ & 2 & $(25.0)$ & $0.893^{\mathrm{NS}}$ \\
\hline
\end{tabular}


Table-VIII shows the relationship between Bishop's score and induction to full dilatation interval of the two study groups. Both the groups (misoprostol and Foley's catheter) showed a negative $(\mathrm{r}=0.836$ and 0.763 , respectively) and highly significant $(\mathrm{P}<0.001$ in both groups) relationship, that is, increase in Bishop's score, reduce the induction-full dilatation interval.

\section{Table-VIII}

\section{Relationship of Bishop's score with induction-full dilatation interval}

Induction-full dilatation interval (hours) Misoprostol

\begin{tabular}{lcc}
$\begin{array}{l}\text { Bishop's } \\
\text { Score }\end{array}$ & $\begin{array}{c}\text { group } \\
(\text { Mean } \pm \text { SD) }\end{array}$ & $\begin{array}{c}\text { group } \\
(\text { Mean } \pm \text { SD })\end{array}$ \\
\hline 1 & $25.57 \pm 0.50$ & $26.00 \pm 1.41$ \\
2 & $20.75 \pm 0.96$ & $22.40 \pm 1.52$ \\
3 & $18.00 \pm 1.34$ & $20.14 \pm 1.07$ \\
4 & $18.00 \pm 0.94$ & $20.14 \pm 1.07$ \\
5 & $16.29 \pm 1.11$ & $18.21 \pm 1.67$ \\
r value & -0.836 & -0.763 \\
P value & $0.000^{* * *}$ & $0.000^{* * *}$ \\
\hline
\end{tabular}

Correlation-coefficient (r) test

*** Significant at $\mathrm{P}<0.001$

Nausea/vomiting were present in $4(8.9 \%)$ cases of misoprostol group and none in the Foley's catheter.

Distribution of babies according their 1-minute and 5minute Apgar scores has been shown in table IX. In misoprostol group, 2 (6.1\%) newborn had severe asphyxia at 1-minute Apgar score but improved at 5minute. Similarly, 8 (24.2\%) babies in misoprostol group and 11 (34.4\%) babies in Foley's catheter group had moderate asphyxia at 1-minute Apga score, but almost all of them (except 2 babies of misoprostol group) improved at 5-mintue. Statistical differences were not significant.

The mean $( \pm \mathrm{SD})$ cost was Taka $118.62 \pm 89$ and $160.20 \pm 52.52$, respectively, in misoprostol and Foley's catheter groups (Table-X). Statistically, the difference is significant $(\mathrm{P}<0.01)$.
Table-IX

Distribution and comparison of Apgar score (1-minute and 5-minute) of the babies of the two study groups.

\begin{tabular}{|c|c|c|c|c|}
\hline \multirow[t]{2}{*}{ Indications } & \multicolumn{2}{|c|}{$\begin{array}{l}\text { Misoprostol } \\
\text { group }(n=33)\end{array}$} & \multicolumn{2}{|c|}{$\begin{array}{c}\text { Foley's } \\
\text { catheter } \\
\text { group }(n=32)\end{array}$} \\
\hline & No. & $(\%)$ & No. & $(\%)$ \\
\hline \multicolumn{5}{|l|}{ 1-minute } \\
\hline$\leq 3$ & 2 & $(6.1)$ & 0 & \\
\hline $4-6$ & 8 & $(24.2)$ & 11 & $(34.4)$ \\
\hline$\geq 7$ & 23 & $(69.7)$ & 21 & $(65.6)$ \\
\hline \multicolumn{5}{|c|}{$\mathrm{X}^{2}=2.5 .50, \mathrm{df}=2, \mathrm{P}=0.279$ (not significant) } \\
\hline \multicolumn{5}{|c|}{5 -minute } \\
\hline$\leq 3$ & 0 & & 0 & \\
\hline $4-6$ & 2 & $(6.1)$ & 0 & \\
\hline$\geq 7$ & 31 & (93.9) & 32 & (100.0) \\
\hline \multicolumn{5}{|c|}{$\mathrm{X}^{2}=2.001, \mathrm{df}=1, \mathrm{P}=0.157^{\mathrm{NS}}$} \\
\hline
\end{tabular}

Table-X

\begin{tabular}{|c|c|c|}
\hline \multicolumn{3}{|c|}{$\begin{array}{c}\text { Cost involvement in the two groups } \\
\text { of study subjects }\end{array}$} \\
\hline Groups & $\begin{array}{l}\text { Cost (Taka) } \\
(\text { Mean } \pm \text { SD) }\end{array}$ & $\mathrm{P}_{\text {value }}^{\mathrm{a}}$ \\
\hline Misoprostol $(\mathrm{n}=45)$ & $118.62 \pm 68.89$ & \\
\hline Foley's catheter $(n=45)$ & $160.20 \pm 52.52$ & \\
\hline
\end{tabular}

aUnpaired Student's ' $t$ ' test

** Significant at $\mathrm{P}<0.01$

\section{Discussion:}

The need to ripe the cervix prior to induction of labour has become a reality in our lives as obstetricians. Analysis of the United States birth statistics (National Center for Health Statistics) shows that approximately 10 percent of all inductions require cervical ripening. With improving maternal and perinatal care in Bangladesh, more pregnant women will be identified with one or other indications for induction and be referred to the hospitals. The purpose of this study was to highlight a simple method for ripening of cervix that may be suitable for an obstetrical unit. 
In this study, 90 patients were selected by simple randomization, 45 in each group (misoprotol and Foley's catheter). Demographic, socioeconomic and obstetric characteristics were compared between the two study groups. None of these characteristics showed any significant difference between these two groups.

Prostglandins are currently the most commonly used agents for the ripening of unfavorable cervix and for induction of labor. These pharmacologic agents are, however, unstable and may have less potency if they are not stored properly and their effects are not readily reversible. However, misoprostol tablets do not require any special temperature to store, and they are available in strips like other normal tablets. Prostaglandins have some disadvantages, such as variable absorption, unpredictable systemic side effect etc. No pharmacologic methods of cervical ripening and induction of labour possess the advantages of lack of systemic side-effects and easy reversibility.

Foley's catheter has been used to ripen the cervix prior to surgical induction of labour. ${ }^{6}$ When women with low Bishop's score and unripe cervix are subjected to induction by Foley's catheter, it helped in ripening of the cervix. Inflated Foley's catheter when placed extra amniotically has been found to improve the inducibility of cervix. ${ }^{7,8}$ The main argument against the use of this method could be the risk of introduction of infection because many potential pathogens inhabit vagina and endo-cervix. But the risk was not quantitatively assessed. These risks can be eliminated by aseptic precautions, and use of aseptic techniques during the insertion of catheters, and the use of sterile water for inflating the balloon. In the present series, it was not possible to ensure that there was no obvious vaginal infection in all of these patients as there were limited facilities available for culture and sensitivity tests for high vaginal and endo cervical swabs. Sandhu et al. in their study reported that the rate of infection with Foley's catheter method is not significant and is comparable to the incidence of hospital acquired infection as stated by different authors with different procedures. ${ }^{8}$

The results from this small study show that an inflated Foley's catheter placed in the extra amniotic space was as efficient as intra-vaginal misoprostol tablet, in ripening the unfavorable cervix. The success of induction of labour was apparently similar in both the groups. The number of caesarean section was 9 $(20 \%)$ in misoprostol group, whereas it was 8 $(17.8 \%)$ in Foley's catheter group. Though there was higher Caesarean section in misoprostol group, but statistically there was no significant difference. The Caesarean section was apparently higher in misoprostol group because of uterine hyper stimulation (presence of hypertonous uterine contraction associated with abnormal FHR). These patients were treated immediately with oxygen therapy, left lateral positioning followed by emergency caesarean section. Two of the three newborns had severe asphyxia and had poor Apgar score at 1-minute, but they improved substantially and 5-minute Apgar score became 10 after neonatal resuscitation.

The use of Foley's catheter was as acceptable to the patients as the misoprostol intravaginal tablet. None of the babies or the mothers had any adverse reaction. None of the patients developed any complication during the period of observation. None of the selected patients had accidental rupture of membrane, antepartum or postpartum pyrexia attributable to the use of Foley's catheter. On the other hand four patients of the misoprostol group developed vomiting. Vomiting was not so severe and simply managed by reassurance to the patient.

The mean $( \pm \mathrm{SD})$ cervical score in misoprostol and Foley's catheter group were $3.20 \pm 1.2$ and $3.62 \pm 1.27$, respectively; and the difference is not statistically significant. Foley's catheter is as effective as vaginal misoprostol in enhancement of inducibility, with similar induction to onset of labour pain interval, induction to full dilatation interval and induction to delivery interval. Outcomes of labour in these two groups are also similar. There was no stillbirth or neonatal death in either group.

Embery and Moleison describe the use of Foley's catheter to effect cervical effacement and dilatation. ${ }^{6}$ They concluded that this method was effective in bringing about the initial effacement and dilatation of the cervix for successful induction.

This study shows that there is a negative correlation between Bishop's score and time of full dilatation of 
cervix, which is similar in both the groups. The findings of this study indicate that pre-induction Bishop's scoring should not be an indicator for selection of method for induction.

We did not find any complain of discomfort on the use of Foley's catheter and it was equally acceptable as misoprostol by the study patients.

Moreover, in misoprostol group, three patients developed hyperstimulation and emergency caesarean section were done in these patients. There was no such side-effect in Foley's catheter group.

In a randomized comparison of oral misoprostol versus Foley's catheter and oxytocin for induction of labour at term, it was found by Abramovici et al. that in multiparous patients the percentage of delivery of neonates within 24 hours and the median induction to delivery time were similar in the two groups. ${ }^{9}$ In nulliparous patients, however, delivery within 24 hours was significantly less likely in the misoprostol group and the median induction to delivery time was longer.

A randomized trial of misoprostol and extraamniotic saline infusion for cervical ripening and labour induction by Shyla et al. showed that both methods of labour induction appeared to be equally effective. ${ }^{10}$

Several studies have shown superiority of the Foley balloon catheter over other techniques, resulting in improved cervical Bishop score, increased rate of labour induction and a higher number of vaginal deliveries. ${ }^{11,12}$

Barkai et al. found no side-effects from the Foley catheter method for either the mother or the baby. ${ }^{13}$

A comparative study of induction of labour by Foley's catheter with that by sweeping of the membrane in prolonged pregnancy by Dewan et al. ${ }^{14}$ showed that induction of labour by Foley's catheter is an effective method of induction of labour, especially in postdated pregnancies with very unripe cervix. It has been found to result in a safe vaginal delivery with short induction delivery interval when compared with induction by sweeping of the membranes.

A clinical study of induction of labour by Foley's catheter was done by Begum et al. ${ }^{15}$ in Sir Salimullah Medical College and Mitford Hospital and found the time interval between insertion of catheter and delivery was in most cases between 24 and 48 hours in the prolonged pregnancy and hypertensive disorder group and more than 48 hours in the IUD group.

In the present study patients median gestational age was 36 weeks in both misoprostol and Foley's catheter groups.

It was also found that low Apgar scores in both the groups, because most of the patients had antepartum eclampsia as well as low gestational age. But all of these distributions are similar in both the groups and so did not affect the results.

The total cost of the procedure was less in misoprostol group (mean Taka 118.62) in comparison to Foley's catheter group (mean Taka 160.20). Statistically the difference is significant $(\mathrm{P}<0.01)$. Although cost involvement was less in misoprostol group, it was not available in our country during the study period. On the other hand, Foley's catheter is easily available everywhere of the country. Moreover, the cost to the Foley's catheter group is not beyond the capacity of the general population. In addition, results of both the groups, in terms of cervical ripening, induction delivery interval, mode of delivery and fetal outcome is similar.

Considering requirement for proper monitoring of mother and fetus, irreversible effect on uterine contraction, which may lead to rupture uterus by misoprostol, lack of adequate facilities of monitoring at peripheral hospitals in Bangladesh, it is beneficial to use Foley's catheter than misoprostol.

\section{Conclusion:}

Though prostaglandins are currently most commonly accepted and widely used agents for the ripening of unfavourable cervix and for induction of labour in the developed countries, but they are associated with some problems, such as absorption, unpredictable patient response, vomiting, diarrhoea, tachycardia, bronchospasm, and some times unavoidable irreversible hypertonic uterine contraction. An alternative approach for cervical ripening has been sought. This alternative approach should be safe, available, preserved at normal temperature, as effective as prostaglandins, cost-effective, less sideeffects and acceptable to the patients as well as to the physicians. Foley's catheter for cervical ripening has 
been found as an alternative method to prostaglandins, as it has almost all the expected criteria. To arrive at a definite conclusion, it is suggested that a long-term study with larger number of subjects need to be carried out to make a plan of action in the selection of method of induction of labour for Bangladeshi women.

\section{References:}

1. Calder AA. Induction and augmentation of labour. In: Edmonds DK, editor. Deqhurst's textbook of obstetrics and gynaecology for postgraduates. 6th ed. Oxford: Blackwell Science Ltd., 1999: 252-8.

2. Rayburn WF. Clinical experience with a controlled release, prostaglandin E2 intravaginal insert in the USA. Br J Obstet Gynaecol 1997; 104(Suppl 15): 8-12.

3. Perry KG, Larman JE, May WL, Robinette LG, Martin RW. Cervical ripening: a randomized comparison between intravaginal misoprostol and an intracervical balloon catheter combined with intravaginal dinoprostane. Am J Obstet Gynecol 1998; 178: 1333-40.

4. Ozan H, Gurkan U, Volkan Y, Melike O, Hana FK, Mephpara T. Misoprostol in labour induction. J Obstet Gynaecol Res 2001; 27: 17-20.

5. Sherman DJ, Frenkel E, Tovbin J, Arieli S, Caspi E, Bukovskyi. Ripening of the unfavorable cervix with extraamniotic catheter balloon: clinical experience and review. Obstet Gynaecol Surv 1996; 51: 612-7.

6. Embery MP, Mollison BG. The unfavourable cervix and induction of labour using a cervical balloon. J Obstet Gynaecol Br Commwlth 1967; 74: 44-8.

7. Anthony CS, Helen M, James SM, Philip AS, Marjorie P, Garrette HC. A prospective, randomized comparison of
Foley catheter versus intracervical prostaglandin E2 gel for preinduction cervical ripening. Am J Obstet Gynecol 1988; 180:180:55-9.

8. Ezimokhai M, Nwabinelli JN. The use of Foley's catheter in ripening the un favourable cervix prior to induction of labour. Br J Obstet Gynaecol 1980; 87: 281-6.

9. Ashrafunness KS, Khatun S, Chowdhury AR, Begum SR, Rashid M, Khatun S. Induction of labour by intracervical prostaglandin gel and oxytocin infusion in primigravid women with unfavourable cervix. Bangladesh Med Res Counc Bull 1997; 23: 66-71.

10. Vengalil SR, Guinn DA, Olabi NF, Burd LI, Owen J. A randomized trial of misoprostol and extraamniotic saline infusion for cervical ripening and labor induction. Obstet Gynecol 1998; 91: 774-9.

11. Atad J, Hallak M, Austender R, Porat-Packer T, Zarfali D, Abramovici $\mathrm{H}$. A randomized comparison of prostaglandin E2, oxytocin and the double-ballon device in inducing labor. Obstet Gynecol 1996; 87: 223-7.

12. Rouben D, Arias F. A randomized trial of extra-amniotic saline infusion plus intracervical Foley catheter balloon versus prostaglandin E2 vaginal fel for ripening the cervix and inducing labor in patients with unfavorable cervix. Obstet Gynecol 1993; 92: 290-4.

13. Barkai G, Cohen SB, Kees L. Induction of labor with use of a Foley catheter and extraamniotic corticosteroids. Am J Obstet Gynecol 1997; 177: 1145-8.

14. Dewan F, Begum R, Chowdhury SB. Comparative study of induction of labour by Foley catheter with that of sweeping of the membrane in prolonged pregnancy. Sir Salimullah Med Coll J 1995; 3:22-7.

15. Begum A, Dewan F, Chowdhury SB. Clinical study of induction of labour by Foley's catheter. Bangladesh J Obset Gynaecol 1996; 11:83-9. 